\title{
Prologue: a new journal, and a farewell to two others
}

It is our pleasure to introduce the first issue of Community Ecology, a new journal formed from a merger of two established ecological publications: Coenoses and Abstracta Botanica. We feel that this merger is a welcome change from the trend of journal proliferation that has pervaded scientific academia in recent years. Community Ecology is intended as a common global forum for community ecologists dealing with plant, animal and/or microbial communities of terrestrial, marine or freshwater environments. The scope of the journal includes, but is not restricted to, the following subject areas:

- Community-based ecological theory.

- Modelling of ecological communities.

- Temporal dynamics, including succession.

- Trophic interactions, including food webs and competition.

- Spatial pattern analysis, including scaling issues.

- Community patterns of species richness and diversity.

- Sampling ecological communities.

- Data analysis methods, including multivariate analysis and geostatistics.

- Community-based ecophysiology.

As we bid a fond farewell to Abstracta Botanica and Coenoses, it is appropriate to summarize the history of these two periodicals and their contribution to the advancement of ecological theory and practice.

\section{Abstracta Botanica}

Abstracta Botanica, founded in 1971 by Prof. T. Simon and J. M. Komlódi of Eötvös University (Budapest), was originally a forum for short versions of scientific theses. The scope of the journal was expanded when Prof. P. Juhász-Nagy became Editor-in-chief in 1984. The journal soon reached a wide international audience, with over half of all contributions coming from outside Hungary. The most successful volumes were special features devoted to symposia proceedings: Time and space: scale dependence of vegetation dynamics (1992, eds. Podani and Fekete), Clonality in plant communities (1995, eds. Oborny and Podani), Cryptogams in the phyllosphere: systematics, distribution, ecology and use (1997, eds. Farkas and Pócs), and Grassland ecology and ecophysiology under elevated atmospheric $\mathrm{CO}_{2}$ and temperature (1997, eds. Tuba, Nagy, Szente and Raschi). A comprehensive memorial volume published in 1993 (In memoriam P. Juhász-Nagy) included thirty contributions in fields ranging from theoretical ecology to hydrobiology and population genetics. The concluding volume of the journal was also published in book form as Scale, Pattern, Fractals and Diversity (1998, eds. Kenkel and Podani). A complete table of contents for Abstacta Botanica is available on the internet at

http://ramet.elte.hu/ podani/abscont.htm.

\section{Coenoses}

Coenoses was established in 1986 by Prof. L. Orlóci (University of Western Ontario, Canada), with strong support from Prof. E. Feoli (University of Trieste, Italy) and P. Juhász-Nagy. The journal was intended as a forum for new theoretical and methodological approaches to community and population studies. The first six issues were published by Edizioni Lint (Trieste), but since 1992 the journal has been under the auspices of the Centre for Theoretical and Applied Ecology (CETA) in Gorizia, Italy. Coenoses has published numerous papers by eminent ecologists from around the world, which is testament to the scientific success of the journal. In addition to the regular volumes, two special issues of Coenoses were published: Statistical Ecology (1995, ed. Patil), and a memorial issue for R. C. Jancey (1997, ed. Patta Pillar). A complete table of contents for Coenoses is available on the internet at

http://ramet.elte.hu/ podani/coentbl.htm. 
While both Coenoses and Abstracta Botanica served the needs of a large scientific community, distribution problems and a lack of 'name' recognition kept both journals in a position of relative obscurity (the quality of journal contributions was never in question). We have come to realize that the only way to address this undesirable situation is to launch a new journal, with a new and more accessible name. By combining previously overlapping editorial boards, we can also better focus our efforts on producing a journal of the highest quality.

Community Ecology is officially established and registered by the Terra Foundation (Debrecen, Hungary) and the Hungarian Ecological Society, and is supported financially by the Hungarian Academy of Sciences. Akadémiai Kiadó (Budapest), a leading central European scientific publishing house, will serve as our publisher and worldwide distributor. They currently publish over forty English-language periodicals, and guarantee high print quality and prompt publication and delivery. Our new publisher also offers an online subscription service, an important advantage in our increasingly networked world. Community Ecology has its own webpage (http://www.terra.hu/comecol), containing information on journal contents, subscriptions, and the preparation of manuscripts for submission.
The Community Ecology editorial board includes scientists who have served previously for Coenoses and/or Abstracta Botanica, as well as some new members. Welcome to all, and thank you for your service to the scientific community. The main task of the editors is to maintain the highest scientific standards in our published papers, by inviting esteemed colleagues from around the world to serve in the peer-review process. While we do not completely agree with the 'impact factor' system and the manner in which it is used for administrative and scientific purposes, we recognize that scientists prefer to publish in well-known and highly regarded journals. We will therefore endeavour to ensure that the very highest standards of scientific research excellence are maintained in our published papers.

It is our hope that Community Ecology will quickly find a 'market niche' in the global community of ecological journals. Readers and subscribers of Coenoses and $\mathrm{Ab}$ stracta Botanica are invited to help us in making this new international endeavour a success.
J. Podani

N. C. Kenkel

Chief Editors 